\title{
Dişil Dindarlık
}

\section{İslamcı Kadın Hareketinin Dönüşümü}

\author{
Zehra YILMAZ \\ İletişim Yayınları, 2015, 284 sayfa, ISBN-13: 978-975-05-1735-8
}

\section{Değerlendiren: Zülal KIR ASANATUCIं* \\ Marmara Üniversitesi Sosyal Bilimler Enstitüsü, Din Sosyolojisi Bilim Dall/ Doktora Öğrencisi.}

Zehra Yılmaz, Başkent Üniversitesi Siyaset Bilimi ve Uluslararası İlişkiler bölümünden mezun olmuş; Ankara Üniversitesi Siyasal Bilgiler Fakültesi'nde " 28 Şubat Sonrası İslamcı Kadınlar" adlı teziyle yüksek lisansını, yine aynı üniversitede "Küreselleşen İslam ve Türkiye'de İslamcı Kadınlar" adlı teziyle de doktorasını tamamlamıştır. Şu an Van Yüzüncü Yıl Üniversitesi'nde öğretim üyesi olarak görevini sürdürmektedir.

Dişil Dindarlık: İslamcı Kadın Hareketinin Dönüşümü adlı kitap, yazarın doktora tezinin kitaba dönüştürülmüş halidir. Bu kitapta yazar, İslamiyet'in temel ilkeleri ve farklı şekillerde yorumlanması ile ilgili tartışmaların eş zamanlı gerçekleşmesinin ne tür bir küresel-yerel paradoks içerdiğini ve İslamcı kadın hareketinin bu paradoks içinde ne şekilde konumlandığını ortaya koymayı hedeflemiştir. Yazarın Müslümanlık yerine "İslamcıllk" kavramını kullanmasının nedeni ise, ona göre İslamcilığın bir inanç sistemi olmasının ötesinde siyasi bir anlam ifade etmesidir. Diğger bir ifadeyle, yazarın ele aldığı konu bağlamında İslamcılık, İslamiyet'in bir din olarak öğretilerine değil, siyasi konjonktürde nasıl bir anlam ifade ettiğine odaklanıyor. Ancak daha işin en başında yani tanımlama ve kavramlarda sıkıntılar olduğu dikkatimizi çekmektedir. Zira yapılan araştırmalar, dışarıdan İslamcı

* zulal.asanatuci@kadem.org.tr 
olarak nitelendirilen kadınların kendilerini bu şekilde tanımlamaktan kaçındıklarını, bunun yerine Müslüman ya da muhafazakâr kavramlarını tercih ettiklerini göstermektedir. 1980'li yıllarda İslami hareket kapsamında görünürlük kazanmaya başlayan ve kendilerini İslamcı olarak nitelendiren kadınlar, özellikle 2000'li yıllardan sonra bu söylemden kaçınmaya başlamışlardır. Bu durum, söz konusu kadınların modernite ile İslami geleneğin bir arada bulunabileceğine yönelik kabullerine işaret etmektedir

İslamcilı̆ı̆n, daha geniş bir ifadeyle dindarlığın yeniden oluşturulmasında, İslamcı kadın hareketinin önemli bir rolü olduğunu belirten yazar, İslamcı hareketin neoliberal küreselleşmeye eklemlenmesi aşamasında ortaya çıkan problemlerin en görünür aktörlerinin kadınlar olduğunu ifade etmektedir. Bu bağlamda İslamcı harekete mensup kadınların, İslam'ın geleneksel biçimlerinden ayrılması sürecinde önemli bir rol oynadıklarını söyleyen yazar; meseleye toplumsal cinsiyet bağlamında yaklaşarak kadınların sosyal yaşam içerisinde ikincil konumda bulunmalarını ve mevcut olan modernleşme modelini eleştirdiklerini ifade ederek kadınların bu anlamda etkin bireyler olarak toplumda görünür olmalarına değinmektedir.

Kitap dört bölümden oluşmaktadır. "İslamcı Hareket İçin Teorik Bir Kaynak: PostKolonyalizm" başlıklı birinci bölümde yazar, "küresel İslam" kavramı ile postkolonyal teorinin eş zamanlı olarak ortaya çıktığını belirtmekte ve postkolonyal teori içerisindeki "madunluk" ve "melezlik" kavramlarının, İslamcı kadınların güçlenme süreç ve stratejilerini anlayabilmek açısından başvurulacak temel kavramlar olduğunu ifade etmektedir. Postkolonyal teori, 1990 sonrası yaşanan küreselleşme sürecinde, küreselleşmenin ortaya çıkış nedenleri ile etkilerini tartışan bir teoridir ve esasen Batı merkezci modernizm anlayışını eleştiren bir teori olarak karşımıza çıkmaktadır. İslamcı hareket ise 1990'lı yıllarda kendisini Batı modernizmi tarafından "dışlanmış" bir yaşam biçimi şeklinde tanımlamaktadır. Bu iki hareketin benzerlikleri de işte bu noktada karşımıza çıkmaktadır. Batı kökenli kolonyal faaliyetler, gelişmemiş ülkelerin ancak Batı'nın modernleşme sürecini takip etmek suretiyle geleneksellikten kurtulup modernleşebileceklerini savunan ve kendi yaşam biçimini bu geleneksel toplumlara çeşitli yöntemlerle empoze etmeye çalışan bir ideoloji olarak ortaya çıımıştır.

Postkolonyal teori çerçevesinde ortaya çıkmış olan iki akımdan söz etmek mümkündür: Bunlardan biri olan "Madun Çalı̧̧maları" grubu ilk olarak Antonio Gramsci tarafından kullanılan "madun" kavramını, teorilerinin temeline yerleştirmiş ve bu kavramı birçok farklılığı bünyesinde barındıran, çoğulcu toplumları ifade etmek için kullanmışlardır. Kelime anlamı itibarı ile madun, toplum içerisinde temsil yeteneği olmayan, en alt kesime işaret etmektedir. Madun kavramından bahsederken akla gelen en önemli isimlerden birisi Gayatri C. Spivak'tır. 
Yılmaz'ın da ifade ettiği gibi Spivak, toplumlarda madun konumunda bulunan kişilerin yalnızca sermaye mantığı göz önünde bulundurularak tanımlanmaması gerektiğini savunarak Marksizm'i eleştirmiştir. $\mathrm{O}$, madunluk kavramı üzerine yapılan tanımlamaları, ataerkil sistem içerisinde ikincil konumda bulunan kadınları da içerisine alacak şekilde genişletmiştir. Bu durumda kadınlar toplum içerisinde erkeklerle eşit haklara sahip olmamaları ve faaliyetlerinin ataerkil zihniyet tarafından kısıtlanması bakımından madun konumunda bulunmaktadırlar.

Yazar, çalışması bağlamında "madun" kavramını, gerek İslami hareketi tanımlarken, gerekse de bu hareketin dönüşümünü incelerken başvurulması gereken bir kavram olarak tanımlamaktadır; İslamcılığın "madunluk" ve "mağdurluk" söylemi üzerinden inşa edildiğini ifade etmekte ve daha sonra "melezlik" söylemi üzerinden küresel neoliberalleşme ve modernleşme sürecine katıldı̆̆ını belirtmektedir. Madun Çalışmaları'nın feminizm ile bağlantısı da, toplumlarda kadının ikincil pozisyonda olması sebebiyle iki kez ötekileştirilmeye maruz bırakılması noktasında karşımıza çıkmaktadır.

Postkolonyal teori çerçevesinde ortaya çıkan akımlardan ikincisi ise, teorilerini "melezlik" kavramına vurgu yaparak oluşturan gruptur. "Melezlik" kavram olarak "madunluk"tan oldukça farklıdır ve kendisini tarihsel süreç içerisinde hiçbir dönemde tamamen saf bir kimliğin bulunmadığı fikri üzerine inşa etmiştir. Bu bağlam içerisinde ifade etmek gerekirse İslamcılık, modernleşme ve küreselleşme süreçleriyle birlikte Batı kültürüyle karşılaşmış ve bu dönemden sonra geri döndürülemez bir dönüşüm sürecinin içerisine girerek kendisini "melez" bir kimlik üzerinden yeniden inşa etme sürecine girmiştir. Yazarın ifadesiyle melezlik ve kültürlerarası akışkanlık kavramları "mazlum ya da mağdurun, kendisini bastıranlara, aşağılayanlara karşı duyduğu hıncı bir yanıyla ehlileştiren bir yanıyla da mazlumlara/mağdurlara da iktidarda pay sahibi olmaya imkân tanıyan bir süreci tanımlamaktadır" (s.53). Batı'yla karşılaşması sonucu "modern" değerleri benimseyen, fakat içerisinde geleneksel ögeleri de barındırmak suretiyle melez bir kimliğe bürünen İslamcılık kapsamında kadın-erkek ilişkileri, kadın hakları ve kadın bedeninin denetimi gibi konular, yeni İslam’ın ortaya çıkış sürecinde merkezî öneme sahip konular olmuştur.

"İslamcılığın Yeni Aşaması: Küresel İslam ve İslamcı Kadınlar" başlıklı ikinci bölümde ise yazar, neoliberal küreselleşme süreciyle birlikte İslamcıllkta yaşanan dönüşümleri ele almakta, bu dönüşümleri ele alırken de İslamcı kadın öznelerden yola çıkarak hareket etmektedir. Nilüfer Göle gibi bazı sosyal bilimcilere göre İslam, esasen modernleşmenin karşısında değil, alternatif bir modernite oluşturma sürecinde karşımıza çıkan kurucu bir unsurdur. Yazarın konu bağlamında açıklamaya çalıştığı durum ise İslam tarafından oluşturulan bu alternatif modernite 
modelinin, sistem içerisinde kendine yer edinmeye çalıştığıdır. Fakat her ne kadar alternatif bir oluşum içerisinde olduklarını düşünseler de İslamcılar, modernleşmeye eklemlenmeye çalışmaları nedeniyle bu hareketten bağımsız düşünülememektedirler. $\mathrm{Bu}$ noktada İslamcılığın küreselleşmeye eklemlenme biçimleri ile küresel kapitalizmin İslamcılığın dönüşümünde oynadığı role odaklanan yazar, İslamcıların, İslam'ın tüm insanlığa gönderilmiş evrensel bir din olması özelliği ile küreselleşme arasında bir benzerlik olduğu görüşünü benimsediklerini, dolayısıyla İslamiyet'le küreselleşmeyi, bir bakıma uzlaştırmaya çalıştıklarını ifade etmektedir.

Bu bölümün sonunda ise yazar, 1990'lardan sonra İslami söylem içerisindeki ataerkil unsurlara yönelik eleştirileriyle ortaya çıkan İslamcı kadın hareketlerinin, aynı zamanda "madun" söyleminden "melez" söylemine doğru yol aldığını ifade etmektedir. Madun kavramı İslamcı kadınlar tarafından melezliğe geçiş sürecinde "mağdur olmak" şeklinde kullanılmış ve toplum içerisinde etkin olan gruba eklemlenme süreci çerçevesinde şekillenmiştir. İslamcı kadınlar dinin öğretilerinden vazgeçmeden Kuran'ı kadın bakış açısıyla yeniden yorumlayarak kadın hakları tartışmalarına yeni boyutlar kazandırmakta ve bu durum İslamcı kadınların toplum içerisinde kendilerine yeni yollar açma çabalarının bir göstergesi olarak karşımıza çıkmaktadır. Dolayısıyla bu durum İslamcılığı ve daha geniş bir mahiyette dindarlığı, kadınları da baş aktörler olarak içerisine alacak şekilde yeniden inşa etmekte ve toplumsal cinsiyet ilişkileri açısından yeni bir tartışma alanı ortaya çıkarmaktadir.

"İslamcı Kadınların Kendilerini Yeniden Tanımlama Deneyimleri" başlıklı üçüncü bölümde yazar, çalışması dâhilinde derinlemesine görüşmeler yaptığı kişilerin İslam dininin kadına yaklaşımı, İslam'ın çeşitli şekillerde yorumlanmasına kadınların ne şekilde katkıda bulundukları ve günümüzde cereyan eden İslami tartışmalar ile hâkim düzen arasındaki ilişki biçimleri gibi konulardaki görüşlerini aktarmıştır. Yazar bu bölümde ayrıca, yeni ve farklı tarzda bir dindarlığın oluşması sürecinde kadınların aldığı konumun iki farklı sonucu olduğuna değinmiştir. Buna göre Kuran'ın kadın perspektifinden okunmaya başlanmasıyla birlikte kadınlar, geleneksel cinsiyet rollerini neoliberalleşme kapsamında eleştirmeye başlamışlar ve onların bu tutumları gerek dindar gerekse dine uzak yaşayan liberal kesim tarafından desteklenmiştir. Bununla birlikte kadınlar, erkeğe bağımlı bir görüntü sergileyen Müslüman kadın imgesinin yanı sıra Batı perspektifinden görülen "ezilen" Müslüman kadın profilini de eleştirmişlerdir. Bu sonuçlardan ikincisi ise, İslamcılığın Batı ile karşılaştığında farklılığını ortaya koyması gerektiği noktasında karşımıza çıkmaktadır. Bu bağlamda Müslüman kadının bedeni İslami kurallar çerçevesinde mahrem kalması gereken bir unsur olarak ortaya çıkmış, bu durum 
da, İslam'ın esasen koruduğu unsurun kadın olduğu sonucunu doğurmuştur. Dolayısıyla dine ilişkin tartışmaların kadın üzerinden şekillenmesi ile dindarlık dişileşmiştir. Diğer bir deyişle, İslamcı harekete mensup kadınların İslam ve kadın ilişkisini modernizmden, feminizmden ve esasen dinden beslenen eklektik bir bakış açısıyla ele almaları, dini kadın bedeni üzerinden kamusal alana taşımış ve ortaya çıkan yeni dindarlık bu kez kadın eliyle inşa edilmeye başlanmıştır. "Dişil dindarlık" kavramı da, yazar tarafından bunların bir sonucu olarak oluşturulmuştur.

Yazar bu bölümde ayrıca, İslamcı hareket içerisinde yer alan İslamcı feminizm tartışmalarına değinmiş, bu bağlamda tesettür örneğini vermiştir. Modernleşme süreciyle birlikte modern değerleri benimseyen İslamcı kadınlar, küreselleşmenin de etkisiyle farklı toplumlarda yaşayan kadınlarla dil, din ve etnisite gibi farklılıkları gözetmeden etkileşim içerisine girmişler; bu da İslamcı kadınların feminizm akımından etkilenmeleri durumunu beraberinde getirmiştir. Örneğin 1980'li yıllarda tesettür konusu ayet ve hadislerle savunulmaya çalışılırken, 1990'lı yılların ortalarından itibaren, Fatma Barbarosoğlu'nun deyimiyle, kadın hakları söylemi üzerinden ifade edilmeye başlanmıştır.

"İslamcı Kadınların Kamusal Görünürlüğü" başlıklı dördüncü ve son bölümde yazar, İslamcı olarak tanımladığı kadınların 1990'lı yıllarla birlikte hayat tarzlarında meydana gelen farklılaşmaların, İslam algısında ve İslami hayat tarzında ortaya çıkardığı farklılaşmaları da içerecek şekilde melez bir biçimde gerçekleştiğini ifade etmiştir. Buna göre muhafazakâr hayat tarzlarını yansıtan tesettürlü kıyafetleriyle İslamcı kadınlar, modernleşme süreciyle birlikte ortaya çıkan farklı yaşam tarzlarını benimsemişler ve tesettürü bir kimlik gibi üzerlerinde taşıyarak kamusal alanda, tesettürün, farklı hayat tarzlarına mensup bireylerin yaptıklarını yapmaya engel olmadığı izlenimini vermeye çalışarak toplumsal hayatın her alanında görünürlük kazanmaya başlamışlardır.

Yılmaz'ın bu kitabı, bir doktora tezi olarak kaleme alınmış olması nedeniyle, teori ve alan araştırması bakımından birbirini destekler nitelikte yazılmıştır. Hemen hemen her bölümde yazar, yaptığı alan araştırması kapsamında elde ettiği sonuçları okuyucuya aktarırken kişisel düşüncelerini ortaya koymaktan kaçınmış, okuyucuyu kendi yorumunu yapması konusunda özgür bırakmıştır. Ancak son bölümde İslamcı kadınların kamusal alanda görünürlüğünün artması konusunda onlara pasif bireylermiş gibi yaklaşması, yazarın bu tarafsız çizgiden uzaklaşmasına sebep olmuştur. Daha açık ifade etmek gerekirse yazar, örneğin "kadınların bugün mecliste başörtüleriyle görünmeleri kadın olmalarından çok dindarlıklarını işaretlemektedir" (s.205-206) cümlesiyle tesettürlü kadınların başardıkları işlerden ziyade, başörtülerinin dinî bir simge gibi görünerek dindarlıklarını pekiştirdi- 
ğini, toplum genelinde de böyle bir algı olduğunu ifade etmiştir. Ayrıca tesettürlü kadın öznelerin, ne şekilde davranmaları gerektiği konusunda eril dünyanın buyruklarını sorgulamadan uyguladığını belirterek, bu durumun İslamcı kadınların hak taleplerini siyasi bir söylem olmaktan ziyade ahlaki bir boyuta çektiğini ifade etmiştir. Esasen toplum genelinde, özellikle siyasal alan içerisinde erkek egemen bir dil hâkimse ve kurallar eril söylem üzerinden belirleniyor ve kadınların bu kalıplara uygun davranmaları bekleniyorsa, bu durumun yalnızca tesettürlü kadınlar için değil, farklı kesimlerden olan kadınlar için de geçerli olduğunu ifade etmek mümkündür.

Yazar, İslamcı kesime mensup kadınların, kadın meselesini Batı kökenli modernleşme karşısında savunulması gereken ahlaki bir değer gibi gördüklerini ve aile kurumuna da bu kapsamda büyük bir değer atfettiklerini ifade etmektedir. Dolayısıyla da bu durumun kadınları güçlendirse de özgürleştirmediğini vurgulamakta ve bunun yalnızca İslam'ın yeniden üretilmesine katkı sağladığını belirtmektedir. Yazar bu bakış açısı ile kadın hareketi içerisinde yalnızca tek tip bir kadın profilini ideal olarak sunmakta ve İslami değerleri öncelikli konumda bulundurarak ortaya çıkmış bir kadın hareketinin, kadınların elde ettikleri kazanımlar çerçevesinde çok da etkili olmadığını savunmaktadır. 